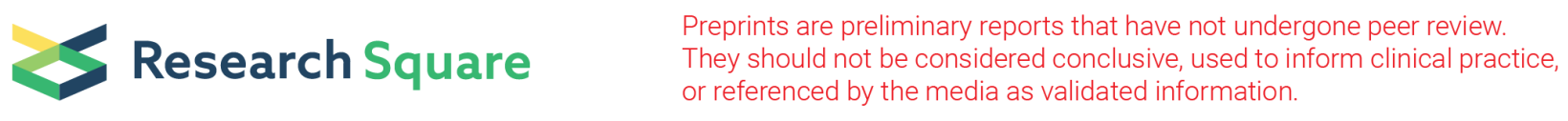

\title{
Net Economic Benefits from Shifting Consumption, Labor Elasticity, and Productivity Gains During an Accelerated Renewable Energy Transition in China
}

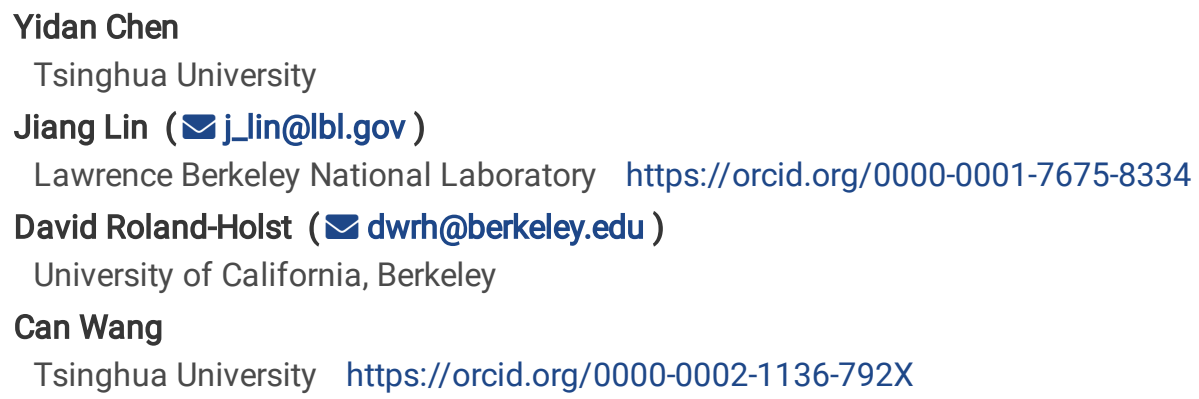

Yidan Chen

Tsinghua University

Jiang Lin ( $\nabla$ j_lin@lbl.gov )

Lawrence Berkeley National Laboratory https://orcid.org/0000-0001-7675-8334

David Roland-Holst ( $\square$ dwrh@berkeley.edu )

University of California, Berkeley

Can Wang

Tsinghua University https://orcid.org/0000-0002-1136-792X

\section{Physical Sciences - Article}

Keywords: Shifting Consumption Patterns, Labor Supply Elasticity, Productivity Gains, Accelerated Renewable Energy Transition

Posted Date: September 22nd, 2020

DOI: https://doi.org/10.21203/rs.3.rs-79754/v1

License: (a) (i) This work is licensed under a Creative Commons Attribution 4.0 International License. Read Full License 


\section{Abstract}

China is the world's largest greenhouse gas (GHG) emitter, but declining wind and solar energy costs present opportunities to transform its electric power sector. In 2017, China launched a national emission trading scheme (ETS). Evidence to date suggests that the ETS mitigates $\mathrm{CO} 2$ emissions and promotes renewable energy deployment but constrains economic growth. These studies, however, do not account comprehensively for economic impacts. Ours is the first to account for three multiplier effects-shifting consumption patterns, job growth with elastic labor supply, and higher total factor productivity (TFP)-when modeling accelerated renewable electricity growth with the ETS in China. Results from a detailed economic forecasting model show low renewable energy costs interacting with the ETS to slash GHG emissions while directly stimulating incremental net positive economic growth by 2030 , compared with a business-as-usual scenario that assumes slower renewable cost reductions and no ETS. Accounting for the multiplier effects reveals larger potential benefits, including up to $15.6 \%$ of additional GDP growth (over business as usual) by 2030 when shifting consumption patterns, job growth with elastic labor supply, and higher TFP are all considered. These results suggest that China should accelerate its clean energy transition, not only for the air-quality and climate benefits, but also for the broad and positive impact on innovation, employment, and economic growth.

\section{Background}

The People's Republic of China is the world's largest emitter of greenhouse gases (GHGs), $44 \%$ (4.14 billion metric tons of $\mathrm{CO}_{2}$ ) of which came from the electric power system in 2017. ${ }^{1}$ According to its Nationally Determined Contribution to the United Nations Framework Convention on Climate Change, the Chinese government pledged to lower $\mathrm{CO}_{2}$ emissions per unit of GDP by $60 \%-65 \%$ relative to 2005 emissions, increasing the share of non-fossil fuels in primary energy consumption to around $20 \%{ }^{2}$ by 2030 . Accelerating the replacement of traditional energy with renewable substitutes would help transform the power system and reduce carbon emissions. China has already demonstrated rapid growth in renewable electricity generation, which increased from $736 \mathrm{TWh}$ (17\% of total electricity generation) to 1,931 TWh $(26 \%)$ between 2010 and $2019 .^{3}$

Renewable energy costs have experienced an unprecedented decline. Over the past decade, the global weighted-average levelized cost of electricity has fallen by $82 \%$ for photovoltaics (PV), $38 \%$ for onshore wind, and $84 \%$ for battery storage. ${ }^{4-7}$ Even without accounting for the social cost of carbon, all-inclusive costs of electricity from new PV and onshore wind are now below the marginal operating costs of an increasing number of existing coal-fired powerplants. ${ }^{5,6}$ In market economies, this crossover cost trend will support autonomous power system transformation, reduce fossil fuel dependence and related environmental impacts, ${ }^{8-10}$ and reduce wholesale and retail electricity costs. ${ }^{11}$ As a result, new opportunities will arise for cutting consumer and manufacturer energy costs, improving human welfare, and boosting economic growth.

The computable general equilibrium (CGE) model is an important tool for studying these macroeconomic impacts. The progress of energy technology in the CGE model is generally characterized by homogeneous autonomous energy efficiency improvement (AEEI) across the economy ${ }^{12,13}$ or average AEEls for different energy-consuming sectors, ${ }^{14,15}$ but neither approach distinguishes technological improvement for different energy sources. Huang et al. (2019) use an exogenously specified mix of fossil and renewable energy as a baseline to describe the process of renewable energy substitution along China's future low-carbon development pathway. ${ }^{16}$ However, the exogenous generation mix does not capture the recent cost crossover-with the cost of renewables dropping below the cost of coal power-nor does it evaluate the full economic impacts of technology improvement. Therefore, there is a need for studies that consider both the plummeting renewable energy costs and the associated economic and social impacts.

Carbon emission trading scheme (ETS) is among the most potentially impactful approaches to driving the renewable transition. In 2011, China launched a pilot ETS covering seven leading provinces and cities including Beijing, Shanghai, Guangdong, Shenzhen, Tianjin, Chongqing, and Hubei. By the middle of 2019, the cumulative trading volume of the pilot ETS covered 330 million metric tons of $\mathrm{CO}_{2}$ equivalent emissions, with a cumulative transaction value of 7.11 billion RMB. ${ }^{17}$ In December 2017, China officially launched its national ETS, and electric power was the first industry included in the system. ${ }^{18}$

To date, the research literature suggests that China's ETS mitigates $\mathrm{CO}_{2}$ emissions and promotes renewable energy deployment but hinders the economy-although there is significant disagreement about the magnitude and direction of net economic impacts. Chen et al. (2020) find that a $1 \%$ carbon emission reduction would reduce GDP by $0.06 \%,{ }^{19}$ whereas Zhang et al. (2018) indicate that the ETS could reduce carbon intensity by $20 \%$ without GDP loss. ${ }^{20}$ Most studies show a negative net impact on the economy due to the ETS, 
ranging from $0.08 \%$ to $5.61 \%$ of real $\mathrm{GDP}^{12,21}$ and depending on carbon pricing, ${ }^{22}$ the allowance allocation mechanism, ${ }^{15,23-25}$ revenue redistribution methods, ${ }^{16,26}$ government fines, ${ }^{27}$ and coverage considered. ${ }^{13,14,28}$ The price-directed nature of the ETS still confers efficiency gains compared with mandated emission caps. ${ }^{29,30}$ However, few studies focus on the comprehensive impact of renewable technology promotion and the ETS in the context of the renewable energy cost crossover.

Further, the existing literature does not account for three critical multiplier effects that could magnify the impacts of accelerating China's renewable electricity transition through technology improvement and the ETS. First, households can be expected to divert the electricity cost savings that result from rapidly declining renewable energy costs toward other expenditures, promoting broad-based economic growth from the demand side. Second, because China generally has a higher elasticity of labor supply compared with developed countries, this more accommodating labor supply will amplify economic gains due to the expenditure stimulus, particularly in the long term. Third, increasing renewable energy use may increase regional total factor productivity (TFP), supporting the anecdotal narrative of a virtuous productivity cycle linking renewable energy deployment to other technological innovation; although the exact mechanisms are difficult to disentangle, studies in diverse settings suggest a positive linkage. ${ }^{31-33}$ Tugcu (2013) estimates long-run (short-run) growth elasticities are -2.1 (-1.7) and 0.8 (0.7) for fossil and renewable consumption, respectively. ${ }^{34}$ Yan et al. (2020) study the relationship between renewable energy technology innovations and China's green productivity growth, finding a significant effect in provinces where income is above a certain threshold. ${ }^{35}$

Ours is the first study to account for the economic impacts of shifting consumption patterns, job growth in the context of elastic labor supply, and higher TFP when simulating accelerated renewable electricity growth with the ETS in China. We employ a dynamic recursive CGE model with a diverse portfolio of electric power technologies to evaluate scenarios designed for illuminating each of the three multiplier effects. Those scenarios are described in the next section, followed by our results and conclusions. The Methods section details our analytical approach.

\section{Scenarios Evaluated}

We evaluate six scenarios (Table 1). In the business as usual (BAU) scenario, the productivity of renewables (wind, solar, and electricity storage) is assumed to follow historical trends (He et al. 2020), ${ }^{11}$ with sustained but moderate cost reductions into the future. In the low-cost renewable scenario $(R)$, more rapid productivity growth in renewables continues in alignment with recent indications, simulating how lower renewable energy costs provide direct stimulus to the economy. In the carbon constraint scenario (C50), total emissions from the power sector by 2030 are limited to $50 \%$ below the 2015 level by instituting an ETS for this sector.

Table 1: Scenarios Evaluated

\begin{tabular}{|ll|}
\hline Scenarios & Description \\
\hline BAU & Moderate productivity improvements in renewables \\
\hline $\mathbf{R}$ & Rapid productivity improvements in renewables \\
\hline C50 & R + ETS limiting $\mathrm{CO}_{2}$ emissions from the power sector to $50 \%$ of the 2015 emissions level \\
\hline Keynes & C50 + shifting expenditure from energy savings \\
\hline EMP & Keynes + more accommodating labor market \\
\hline PROD & EMP + energy productivity spillovers (1\% TFP growth) \\
\hline
\end{tabular}

Our other three scenarios examine the multiplier economic impacts of renewable innovation and the ETS. The Keynes scenario builds on the C50 scenario to elucidate the effects of demand-side aggregate stimulus resulting from energy cost savings due to renewable technology innovation. Previous economic assessments of renewable energy have focused on three component impacts: investment in technology production, technology purchasing, and installation. Technology production (e.g., building and operating a solar panel factory) represents so-called "shovel ready" investment and is usually an unambiguous economic stimulus. Technology purchase and installation costs can have mixed economic effects, depending on the opportunity cost or alternative return to capital. In other words, technology adoption will stimulate the economy if it increases productivity, reduces resource costs, or both. If it reduces productivity or increases resource costs, it will be detrimental to growth. 
The shifting consumption patterns in the Keynes scenario begin with lower-cost electricity saving money for households and enterprises. These savings are diverted toward other expenditures, mostly domestic services that employ workers from all skill levels and demographics and that are non-tradable, meaning these new jobs cannot be outsourced. Because more than half of China's aggregate domestic demand is from household consumption and $70 \%$ of this goes to services, about half of energy cost savings diverted to other expenditures can be expected to go to this employment category-the most labor intensive and skill diverse in the economy. In contrast, the carbon fuel supply chain is among the least employment intensive; for example, the carbon fuel supply chain produces only $1 \%-10 \%$ as many jobs per unit of revenue compared with the service sector, differences far too large to be offset by wage inequality (Figure 1). Simply put, about two thirds of the money saved on cheaper electricity is spent on services, stimulating much stronger and more diverse domestic job growth.

The EMP scenario builds on the Keynes scenario to examine the role of labor supply in economic adjustment. Based on China's dynamism over most of the last two decades, the BAU, R, C50, and Keynes scenarios assume relatively "full employment," which would limit the economy's supply response to positive or negative stimulus. China's reform period has seen dramatic economic growth and large-scale labor mobilization, but over the last decade growth and rates of job creation have moderated (particularly in the post-COVID economy). To reflect this, the EMP scenario assumes a low but nonzero elasticity of aggregate labor supply (0.25), describing a more accommodating labor market.

Finally, the PROD scenario builds on the EMP scenario to exemplify renewable energy productivity spillovers, assuming that accelerated renewable deployment confers an average of $1 \%$ higher TFP growth on the economy. This value is not a forecast; it merely illustrates the growth potential of induced innovation.

\section{Results}

\section{Generation Mix}

As expected, fossil fuel generation becomes increasingly small and renewable generation increasingly large as the renewablepromoting assumptions in our scenarios become increasingly aggressive (Figure 2). In the BAU scenario (moderate productivity improvement in renewables), coal's share of generation declines from $65.9 \%$ in 2017 to $51.3 \%$ in 2030 , while solar's share increases by 8.6 percentage points and wind's share increases by 7.6 percentage points. In the R scenario (more rapid productivity growth and larger renewable cost reductions), solar's share rises by 18.7 percentage points compared with the BAU scenario in 2030 , and wind's share rises by 0.5 percentage points, with coal's share dropping below half. The rapid reduction in technology costs, especially solar costs, directly drives transformation of the power sector from fossil energy to renewable energy. In the C50 scenario (R scenario + ETS limiting power-sector $\mathrm{CO}_{2}$ emissions to $50 \%$ of 2015 levels), the substitution from fossil fuel to renewables in the power sector is further accelerated by the ETS policy. Solar and wind account for $54.4 \%$ of generation in 2030, and coal falls to $21.1 \%$. In the Keynes, EMP, and PROD scenarios, changes in consumption patterns, labor supply, and productivity spillovers have relatively small impacts on the generation mix compared with the rapid renewable cost reductions and ETS implementation in the C50 scenario; thus, their electricity generation mixes are similar to the mix in the C50 scenario.

\section{$\mathrm{CO}_{2}$ Emissions}

The power-sector $\mathrm{CO}_{2}$ emissions trends in each scenario correspond with the generation trends (Figure 3). In the BAU scenario, the moderate renewable productivity improvement decreases electricity prices, which increases electricity demand. Because coal generation remains the largest component, this rebound effect results in higher emissions. In the $\mathrm{R}$ scenario, total electricity demand is $2.6 \%$ higher than in the BAU scenario owing to lower electricity prices. However, higher renewable penetration more than offsets this effect, and total annual carbon emissions are $4.47 \mathrm{Gt}$ in 2030 , slightly larger than in 2017 but $23 \%$ lower than in the BAU scenario. The remaining scenarios show how transforming the power sector via renewables can reduce $\mathrm{CO}_{2}$ emissions while meeting electricity demand growth. In the C50, Keynes, EMP, and PROD scenarios, power-sector $\mathrm{CO}_{2}$ emissions are reduced by the cap of $50 \%$ below 2015 levels, at $1.92 \mathrm{Gt}$ in 2030 .

\section{Economic Impacts}

Compared with our BAU scenario, all of our other scenarios grow China's economy (Tables 2 and 3). In the R scenario, sustained renewable cost improvements alone more than compensate for the cost of a significant renewable buildout, adding over 607 billion

Page $4 / 11$ 
$\mathrm{RMB}$ or $0.4 \%$ to China's real GDP by 2030. Even the $\mathrm{C} 50$ scenario, with its aggressive $\mathrm{CO}_{2}$ mitigation strategies, results in positive growth owing to low-cost renewables. In both these scenarios, aggregate investment grows more slowly than in the BAU scenario, but overall economic growth and real consumption are higher. Lower electricity costs also translate into greater Chinese competitiveness, with beneficial impacts on exports and (to a lesser extent) imports.

In economics, general equilibrium, indirect, and induced effects often outweigh direct effects. This is apparent in the Keynes scenario, which accounts explicitly for expenditure diversion from electric power to other goods and services. This multiplier effect increases real GDP significantly. Compared with the C50 scenario on which it is based, the Keynes scenario adds 2,020.5 billion RMB to GDP in 2030. The Keynes scenario increases GDP by $1.3 \%$ over the BAU scenario, compared with the C50 scenario's $0.1 \%$ increase over the BAU scenario.

Table 2: Macroeconomic Impacts in China (change from 2030 BAU in real billion RMB)

\begin{tabular}{|llllll|}
\hline & R & C50 & Keynes & EMP & PROD \\
\hline GDP & 607.4 & 228.6 & $2,249.1$ & $11,959.7$ & $26,998.1$ \\
\hline Consumption & 490.0 & 329.1 & $1,051.7$ & $3,871.5$ & $8,697.3$ \\
\hline Investment & -897.8 & $-1,048.1$ & $1,984.5$ & $7,044.2$ & $14,426.5$ \\
\hline Exports & 267.0 & 229.4 & -518.8 & $1,112.3$ & $4,450.1$ \\
\hline Imports & 97.9 & 113.8 & $1,057.6$ & $1,278.6$ & $2,424.3$ \\
\hline Employment (million full-time equivalent jobs) & 1.2 & 0.7 & 1.7 & 66.6 & 79.0 \\
\hline
\end{tabular}

Table 3: Macroeconomic Impacts in China (percent change from BAU in 2030)

\begin{tabular}{|llllll|}
\hline & R & C50 & Keynes & EMP & PROD \\
\hline GDP & $0.4 \%$ & $0.1 \%$ & $1.3 \%$ & $6.9 \%$ & $15.6 \%$ \\
\hline Consumption & $0.8 \%$ & $0.5 \%$ & $1.7 \%$ & $6.2 \%$ & $13.9 \%$ \\
\hline Investment & $-1.3 \%$ & $-1.6 \%$ & $2.9 \%$ & $10.5 \%$ & $21.4 \%$ \\
\hline Exports & $0.8 \%$ & $0.7 \%$ & $-1.6 \%$ & $3.4 \%$ & $13.5 \%$ \\
\hline Imports & $0.5 \%$ & $0.6 \%$ & $5.4 \%$ & $6.6 \%$ & $12.5 \%$ \\
\hline Employment & $0.1 \%$ & $0.1 \%$ & $0.2 \%$ & $7.9 \%$ & $9.4 \%$ \\
\hline
\end{tabular}

Although the economic stimulus in the R, C50, and Keynes scenarios is positive, the growth dividend from lower-cost energy is less than $1.5 \%$ in 2030 . To a significant extent, this is due to assumed resource constraints, particularly in labor markets. China can import natural resources without difficulty (but possibly with terms of trade effects), but we assume a very inelastic (0.125) aggregate labor supply in the R, C50, and Keynes scenarios. When we relax this constraint modestly (to 0.25 ) in the EMP scenario, the benefits of renewable energy stimulus increase dramatically. Incremental GDP in 2030 rises from $1.3 \%$ in the Keynes scenario to $6.9 \%$ in the EMP scenario, adding 9.7 trillion RMB and 64.9 million full-time equivalent jobs to the overall economy. In other words, renewable electricity can be growth positive but also strongly counter-cyclical, contributing even more to growth in adverse labor markets, such as during the pandemic-induced economic downturn.

Finally, the PROD scenario demonstrates the substantial growth potential of productivity spillovers from an economywide renewable energy transition-for illustrative purposes only, because evidence is insufficient to estimate such induced productivity effects econometrically for China. The 1\% annual TFP increase in the PROD scenario more than doubles economic growth compared with the EMP scenario, adding $15.6 \%$ to real GDP in just over a decade. This scenario is a reminder that China's most dynamic growth experiences-extending from the 1990s to 2005-depended not only on massive infrastructure investments, but also on significant technological progress. In the case of electric power, infrastructure also grew very rapidly, but technological progress has still been 
limited. New, clean energy technology can be instrumental in helping the economy achieve its full potential, improving material living standards and quality of life across China.

\section{Conclusion}

In the wake of two decades of renewable energy innovations, it has become increasingly clear that the perceived tradeoff between economic growth and climate risk reduction is based on a fallacy. Low- and zero-emission electricity generation costs are falling below costs of carbon-fueled generation, and renewable energy co-benefits such as air-quality improvements are becoming ever more apparent. Nowhere is the issue more compelling than in China, which for several decades has developed electric capacity faster than any other country and now has the world's largest renewable energy sector. Recognizing the need for a low-carbon transition, China is experimenting with aggressive mitigation policies, including technology standards, ETS policies, and carbon taxation.

Using a detailed forecasting model for China's economy, we show how falling renewable energy technology costs can interact with a market-based ETS to deliver dramatic GHG reductions with net positive aggregate economic growth. This finding supports plentiful recent evidence of the impacts from renewable electricity costs dropping below grid parity, but we extend the economic analysis to identify other growth drivers. These include as-yet unrecognized multiplier and productivity spillovers. First, energy cost savings for households and enterprises permit expenditure shifting toward more diverse, labor-intensive goods and services, compared with the carbon fuel supply chain. Because the new expenditure focuses on services, this process stimulates new, broad-based domestic income and job creation-especially when labor supply is relatively elastic. Second, economic benefits brought about by technological progress have been neglected or underestimated in previous studies, yet modernization of the energy system can be expected to yield productivity benefits via technology spillovers. Although the exact magnitude of such impacts is an empirical question, the pervasiveness of energy services suggests it will be substantial.

These results have two important implications. First, the economic benefits of renewable energy substantially exceed their direct costs, and adoption of renewable technologies can proceed without the still-controversial interventions needed to recognize the social cost of carbon in the coming decade. Second, modernizing the electric power system can support a new generation of more diverse domestic job creation, facilitating an essential transition for millions of workers in the carbon fuel supply chain, one of the last great artifacts of the Industrial Age.

Overall, our results suggest that China should accelerate its clean energy transition, not only for the air-quality and climate benefits, but also for the broad and positive impact on innovation, employment, and economic growth. As China considers its post-COVID recovery measures, building green energy infrastructure should simultaneously support sustained economic growth and climate mitigation.

\section{Methods}

We use the PRC Aggregated National Development Assessment (PANDA) model, a dynamic CGE model of the Chinese economy constructed at the University of California, Berkeley, which has been used to analyze China's energy and climate policies. ${ }^{* 16,38}$ The current version of the PANDA model is calibrated to the 2017 China Input-Output table, ${ }^{36}$ with 42 aggregated production sectors. To better analyze the economic impacts of renewable energy cost reductions, we disaggregate the power sector into electricity transmission, electricity storage, and eight different generation technologies (coal, natural gas, oil, nuclear, hydropower, wind, solar, and biomass) following the methods by Mu et al. ${ }^{13}$ and Wing. ${ }^{39}$ The generation shares by technology type are based on data from the China Electricity Council, ${ }^{3}$ whereas the cost shares by investment, operations and maintenance, and fuel for each technology are based on levelized cost data from the International Energy Agency ${ }^{40}$ and He et al. ${ }^{11}$

\section{Core Model}

In the production block, the constant elasticity of substitution (CES) function, the most common non-linear function for CGE models, is used to represent the different substitution possibilities across different inputs in each sector (Figure 4). The non-energy intermediate demand (ND) bundle-where the intermediate demand follows the fixed proportion input-output relationship (the Leontief function, a special form of the CES function with zero substitution elasticity)-is combined with the capital-energy-labor (KEL) bundle to generate the final output. The KEL bundle consists of the labor demand (AL) bundle and capital-energy (KE) bundle. In the third level, the AL bundle is split into labor demand by skill, whereas the KE bundle is split into energy and capital. In the fourth level, the energy demands by fuel type are combined to generate energy output. 
In the consumption block, the PANDA model includes households and government as the two representative consumers. Household income from labor wages, investment income, and transfer payments is allocated to expenditures on goods and saving by an exogenous rate calibrated to the social accounting matrix. Each representative household is assumed to maximize utility by consuming different goods and services as modeled by the Linear Expenditure System specification. The government receives revenues from various tax instruments (income, indirect trade, and factor taxes), net of subsidies and transfers. Government income is allocated to goods and services, and aggregate expenditures are fixed in real terms.

For international trade, the Armington assumption allows for differentiation between domestic products and imports and exports. In addition, the model simulates this differentiation as an aggregate (XA above), with one domestic Armington agent per product category using Constant Elasticity of Substitution (CES) and Constant Elasticity of Transformation (CET) functions to represent the import and export sides, respectively.

\section{Carbon Emission Trading Block}

A carbon emission trading block is applied to simulate the ETS in the PANDA model. The $\mathrm{CO}_{2}$ emissions of sector $i\left(\mathrm{EF}_{\mathrm{i}}\right)$ equal the inputs from energy sector $e$ to sector $i\left(\mathrm{XAP}_{\mathrm{i}, \mathrm{e}}\right)$ multiplied by the emission factor (emit $\left.\mathrm{i}_{\mathrm{i}, \mathrm{e}}\right)(\mathrm{Eq} .1)$. The $\mathrm{CO}_{2}$ emissions of household $h$ $\left(\mathrm{EF}_{\mathrm{h}}\right)$ equal the inputs from energy sector $e$ to final consumption of household $h\left(\mathrm{XAC}_{\mathrm{h}, \mathrm{e}}\right)$ multiplied by the emission factor (emit $\left.{ }_{\mathrm{h}, \mathrm{e}}\right)$ (Eq. 2). The total $\mathrm{CO}_{2}$ emissions (EFT) equal the sum of emissions from production and households (Eq. 3). The emission factors by energy types, sectors, and households are calculated by aggregating 20 fuel types into 4 energy sectors and disaggregating the consuming sectors to be more consistent with the production sectors, based on the China national $\mathrm{CO}_{2}$ emission inventory (sectoral approach) from Shan et al. ${ }^{1}$

$$
\begin{aligned}
E F_{i} & =\sum_{e} e m i t_{i, e} \times x a p_{i, e} \\
E F_{h} & =\sum_{e} e m i t_{h, e} \times x a c_{i, e} \\
E F T & =\sum_{i} E F_{i}+\sum_{h} E F_{h}
\end{aligned}
$$

In this study, the power industry is the only sector controlled by the national ETS. The total annual carbon emissions for the power sector (EFcap ieiec) are set exogenously (Eq. 4). To meet the $\mathrm{CO}_{2}$ emissions constraints, a shadow carbon price $(\mu)$ for each unit of $\mathrm{CO}_{2}$ is introduced into the model. Each unit of emissions in the power generation process requires an additional payment (Ctax ieiec,e $\left._{2}\right)$ to the production function (Eq. 5). When $\mathrm{CO}_{2}$ emissions constraints on the power sector are introduced into the economic system in terms of affecting production costs and producers' behavior, the system eventually reaches a new equilibrium.

$$
\begin{gathered}
E F \text { cap }_{\text {ielec }}=E F_{\text {ielec }}=\sum_{e} \text { emit }_{\text {ielec, }, e} \times \text { xap }_{\text {ielec, }, e} \\
\text { Ctax }_{\text {ielec, }, e}=\mu \times \text { emit }_{\text {ielec }, e}
\end{gathered}
$$

* PANDA was developed in 2005 by David Roland-Holst and is fully documented here: http://www.bearecon.com/PANDA_Technical191015.pdf.

\section{References}

1. Shan, Y., Huang, Q., Guan, D. \& Hubacek, K. China Co2 Emission Accounts 2016-2017. Sci Data. 7, (2020).

2. National Development and Reform Commission of China (NDRC). Enhanced Actions On Climate Change: China's Intended Naitonally Determined Contributions.

https://www4.unfccc.int/sites/ndcstaging/PublishedDocuments/China\%20First/China\%27s\%20First\%20NDC\%20Submission.pdf (2015)

3. China Electricity Council. China Electricity Statistical Database. https://www.cec.org.cn/menu/index.html?542.

4. BloombergNEF. New Energy Outlook 2019., 2019.

5. IRENA. Renewable Power Generation Costs in 2019., 2020.

6. LAZARD. Lazard's Levelized Cost of Energy Analysis - Version 13.0., 2019.

7. LAZARD. Lazard's Levelized Cost of Storage Analysis - Version 5.0., 2019. 
8. New Climate Institute. Bringing Climate Policy Up to Date - Decreasing Cost Projections for Renewable Energy and Batteries and their Implications - Case Study Chile., 2019.

9. U.S. Energy Information Administration. Effects of Renewable Technology Capital Costs On Electricity Capacity and Generation in Two Illustrative Regions., 2020.

10. Azimoh, C. L., Paul, B. S. \& Mbohwa, C. Declining Cost of Renewable Energy Technology: An Opportunity for Increasing Electricity Access in Sub-Saharan Africa. 2017 IEEE Electrical Power and Energy Conference (EPEC). Saskatoon, SK, Canada, 2017:1-6.

11. He, G. et al. Rapid Cost Decrease of Renewables and Storage Accelerates the Decarbonization of China'S Power System. Nat Commun. 11, (2020).

12. Li, W., Zhang, Y. \& Lu, C. The Impact On Electric Power Industry Under the Implementation of National Carbon Trading Market in China: A Dynamic Cge Analysis. J. Clean. Prod. 200, 511-523 (2018).

13. Mu, Y., Evans, S., Wang, C. \& Cai, W. How Will Sectoral Coverage Affect the Efficiency of an Emissions Trading System? A CgeBased Case Study of China. Appl. Energ. 227, 403-414 (2018).

14. Lin, B. \& Jia, Z. The Impact of Emission Trading Scheme (Ets) and the Choice of Coverage Industry in Ets: A Case Study in China. Appl. Energ. 205, 1512-1527 (2017).

15. Zhang, L., Li, Y. \& Jia, Z. Impact of Carbon Allowance Allocation On Power Industry in China'S Carbon Trading Market: Computable General Equilibrium Based Analysis. Appl. Energ. 229, 814-827 (2018).

16. Huang, H. et al. Emissions Trading Systems and Social Equity: A Cge Assessment for China. Appl. Energ. 235, 1254-1265 (2019).

17. Ministry of Ecology and Environment of P.R.China (MEE). China's Policies and Actions in Response to Climate Change: 2019 Annual Report (in Chinese)., 2019.

18. NDRC. National Carbon Emissions Trading Scheme Construction Program (Power Generation Industry). https://www.ndrc.gov.cn/xxgk/zcfb/ghxwj/201712/t20171220_960930.html (2017).

19. Liu, Y., Tan, X., Yu, Y. \& Qi, S. Assessment of Impacts of Hubei Pilot Emission Trading Schemes in China - a Cge-Analysis Using Termco2 Model. Appl. Energ. 189, $762-769$ (2017).

20. Zhang, C., Wang, Q., Shi, D., Li, P. \& Cai, W. Scenario-Based Potential Effects of Carbon Trading in China: An Integrated Approach. Appl. Energ. 182, 177-190 (2016).

21. Li, G., Yang, J., Chen, D. \& Hu, S. Impacts of the Coming Emission Trading Scheme On China'S Coal-to-Materials Industry in 2020. Appl. Energ. 195, 837-849 (2017).

22. Lin, B. \& Jia, Z. Impacts of Carbon Price Level in Carbon Emission Trading Market. Appl. Energ. 239, 157-170 (2019).

23. Lin, B. \& Jia, Z. What Will China's Carbon Emission Trading Market Affect with Only Electricity Sector Involvement? A Cge Based Study. Energ. Econ. 78, 301-311 (2019).

24. Tang, L., Wu, J., Yu, L. \& Bao, Q. Carbon Allowance Auction Design of China's Emissions Trading Scheme: A Multi-Agent-Based Approach. Energ. Policy. 102, 30-40 (2017).

25. Li, W. \& Jia, Z. The Impact of Emission Trading Scheme and the Ratio of Free Quota: A Dynamic Recursive Cge Model in China. Appl. Energ. 174, 1-14 (2016).

26. Lin, B. \& Jia, Z. Is Emission Trading Scheme an Opportunity for Renewable Energy in China? A Perspective of Ets Revenue Redistributions. Appl. Energ. 263, 114605 (2020).

27. Lin, B. \& Jia, Z. Energy, Economic and Environmental Impact of Government Fines in China's Carbon Trading Scheme. Sci. Total Environ. 667, 658-670 (2019).

28. Lin, B. \& Jia, Z. Why Do we Suggest Small Sectoral Coverage in China'S Carbon Trading Market? J. Clean. Prod. 257, 120557 (2020).

29. Liu, Z. et al. Regional Impacts of Launching National Carbon Emissions Trading Market: A Case Study of Shanghai. Appl. Energ. 230, 232-240 (2018).

30. Wu, R. et al. Achieving China'S Indc through Carbon Cap-and-Trade: Insights From Shanghai. Appl. Energ. 184, 1114-1122 (2016).

31. Rath, B. N., Akram, V., Bal, D. P. \& Mahalik, M. K. Do Fossil Fuel and Renewable Energy Consumption Affect Total Factor Productivity Growth? Evidence From Cross-Country Data with Policy Insights. Energ. Policy. 127, 186-199 (2019).

32. Tugcu, C. T. \& Tiwari, A. K. Does Renewable and/Or Non-Renewable Energy Consumption Matter for Total Factor Productivity (Tfp) Growth? Evidence From the Brics. Renewable and Sustainable Energy Reviews. 65, 610-616 (2016).

Page 8/11 
33. Ladu, M. G. \& Meleddu, M. Is there any Relationship Between Energy and Tfp (Total Factor Productivity)? A Panel Cointegration Approach for Italian Regions. Energy. 75, 560-567 (2014).

34. Tugcu, C. T. Disaggregate Energy Consumption and Total Factor Productivity: A Cointegration and Causality Analysis for the Turkish Economy. International Journal of Energy Economics and Policy. 3, 307-314 (2013).

35. Yan, Z., Zou, B., Du, K. \& Li, K. Do Renewable Energy Technology Innovations Promote China's Green Productivity Growth? Fresh Evidence From Partially Linear Functional-Coefficient Models. Energ. Econ. 90, 104842 (2020).

36. National Bureau of Statistics (NBS). China Input-Output Tables 2017. http://data.stats.gov.cn/ifnormal.htm? $\mathrm{u}=/$ files/html/quickSearch/trcc/trcc01.html\&h=740 (2020).

37. National Bureau of Statistics (NBS). "China Labor Statistical Yearbook". (2018).

38. Springer, C., Evans, S., Lin, J. \& Roland-Holst, D. Low Carbon Growth in China: The Role of Emissions Trading in a Transitioning Economy. Appl. Energ. 235, 1118-1125 (2019).

39. Sue Wing, I. The Synthesis of Bottom-Up and Top-Down Approaches to Climate Policy Modeling: Electric Power Technology Detail in a Social Accounting Framework. Energ. Econ. 30, 547-573 (2008).

40. International Energy Agency. Projected Costs of Generating Electricity: 2015 Edition., 2015.

\section{Figures}

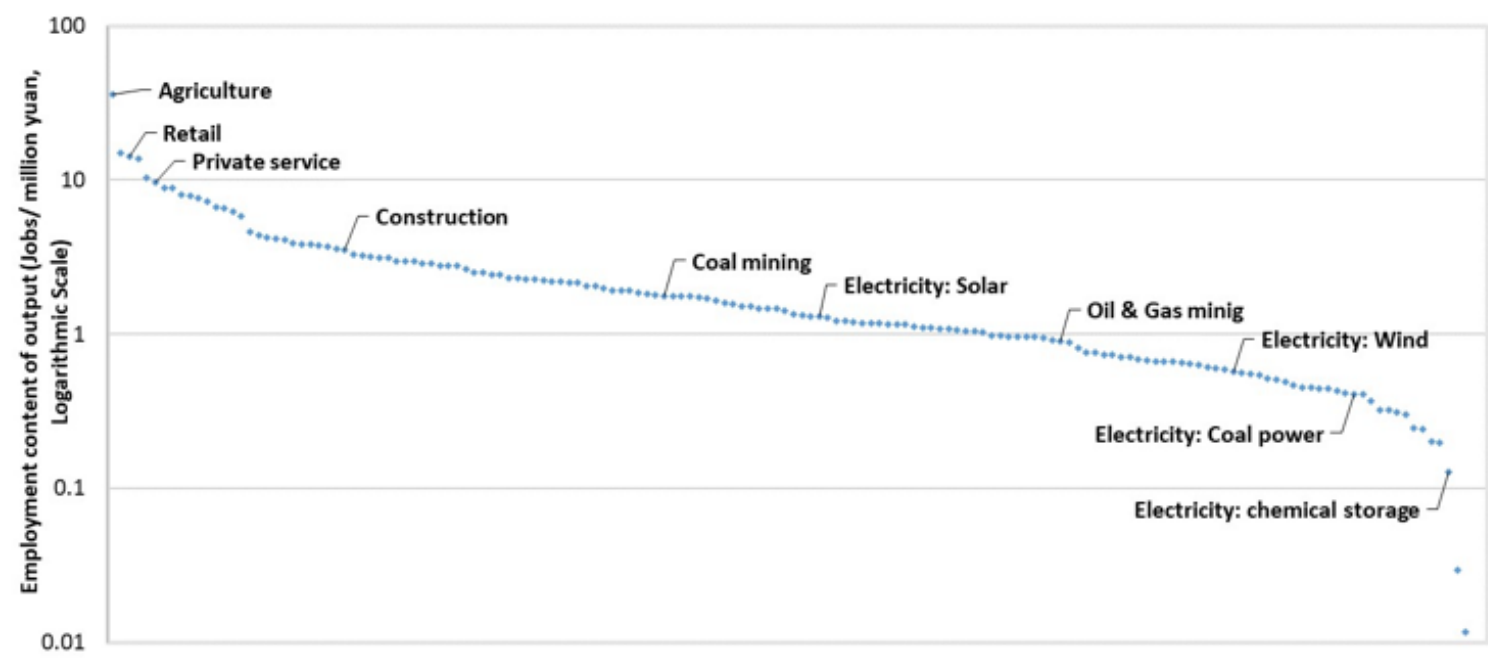

Source: Authors' calculation from official data. ${ }^{36,37}$

\section{Figure 1}

Employment Intensity in China by Sector, 2017 


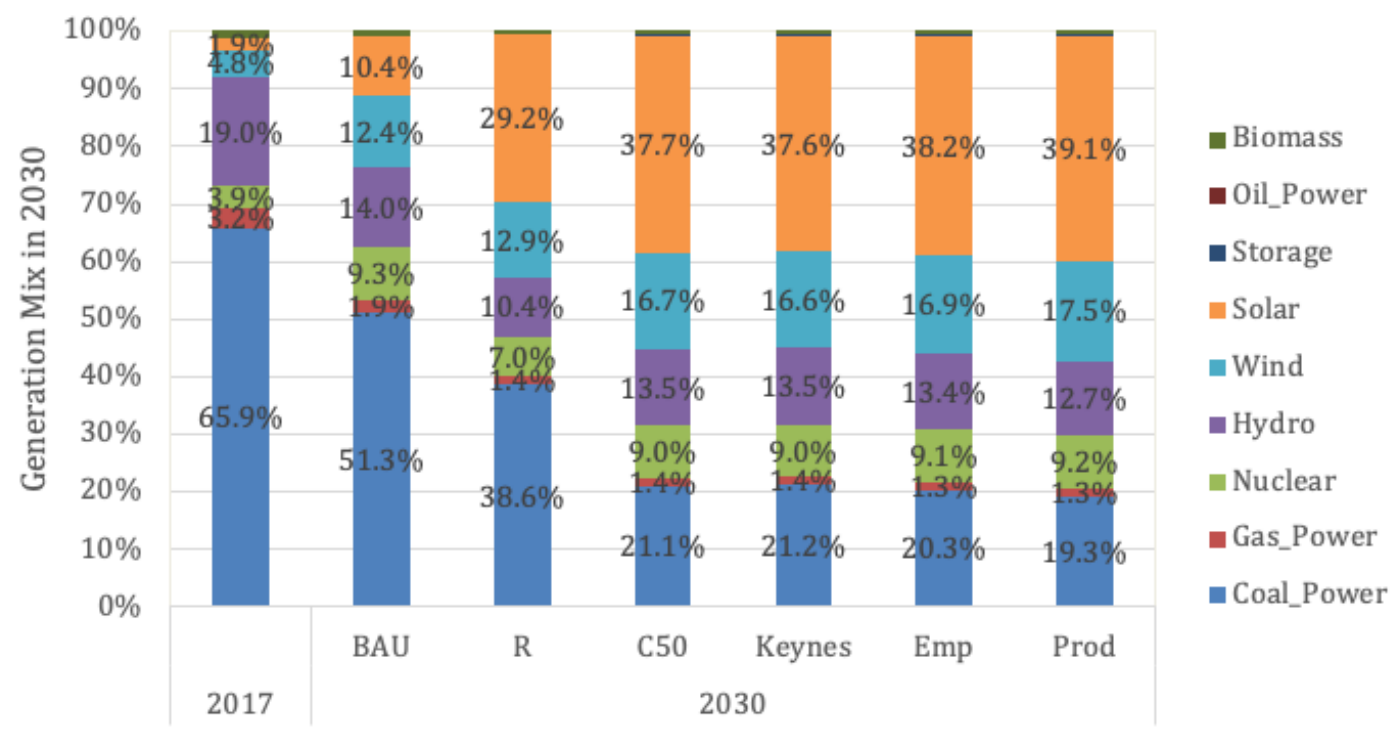

Figure 2

Generation mix of the power sector in the base year (2017) and in 2030

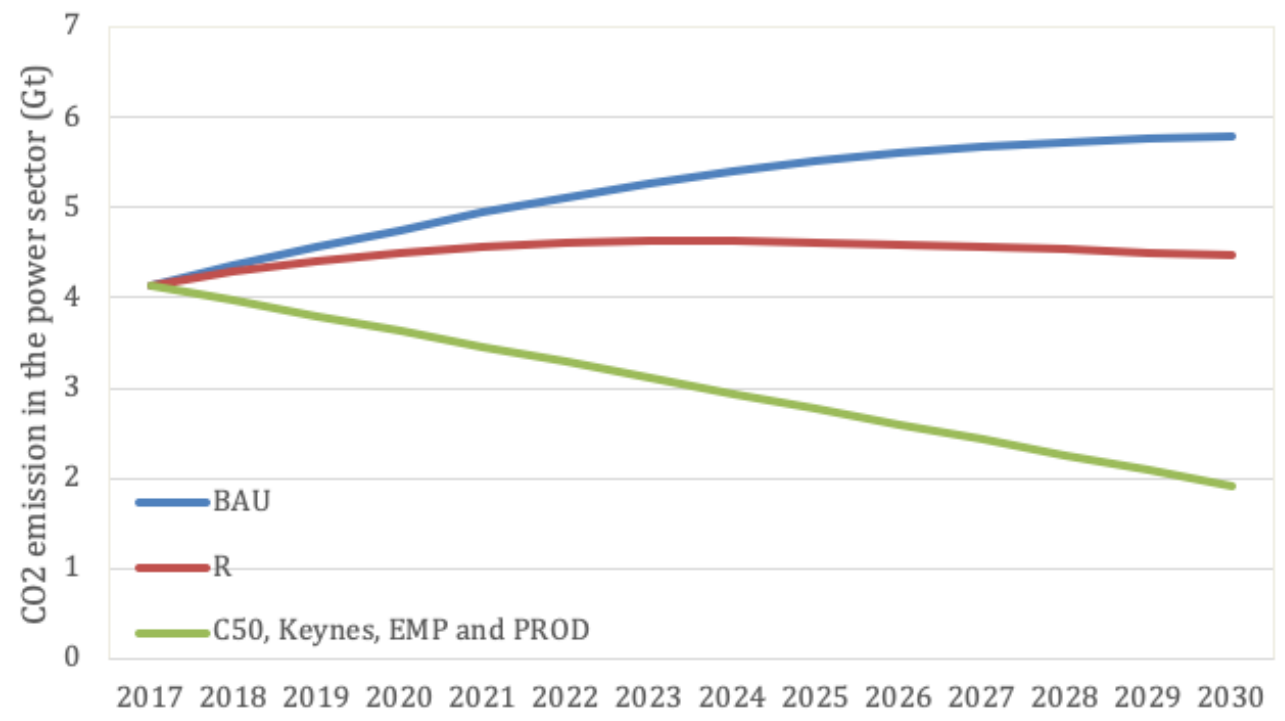

\section{Figure 3}

CO2 emissions in the power sector from 2017 to 2030 


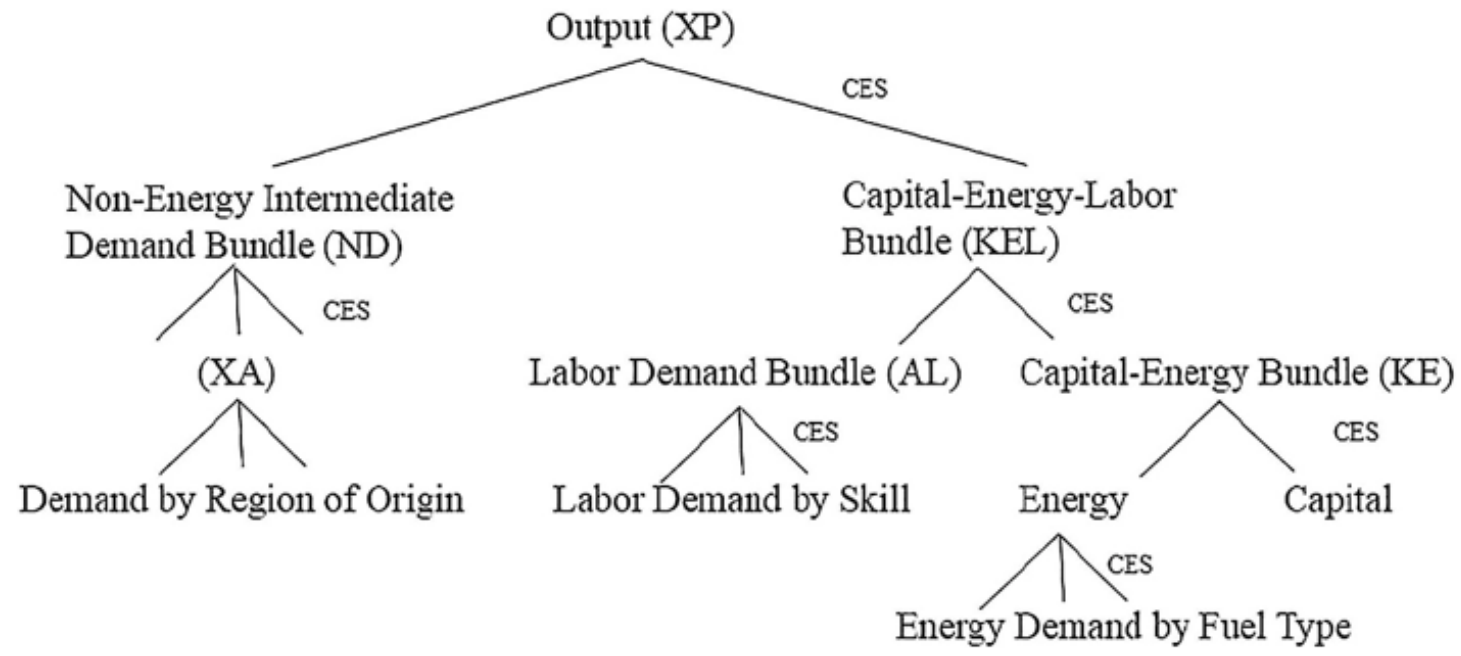

Figure 4

PANDA model production block 